MARIA JUDA* - LUBLIN

\title{
FRAGMENT KSIĘGOZBIORU WILEŃSKICH DOMINIKANÓW W KOLEKCJI KLEMENSOWSKIEJ KSIAZŻICY ZAMOJSKIEJ IM. STANISEAWA KOSTKI ZAMOYSKIEGO
}

\begin{abstract}
Streszczenie
Stare druki, stanowiące fragment księgozbioru dominikanów wileńskich, obecnie przechowywane w Książnicy Zamojskiej im. Stanisława Kostki Zamoyskiego, pochodzą z XVI, XVII i XVIII wieku i są wytworem licznych oficyn zagranicznych i krajowych. Licząca 92 pozycji bibliograficznych kolekcja zawiera dzieła odnoszące się do różnych ówczesnych dziedzin wiedzy ludzkiej, ale ukierunkowana jest na potrzeby zgromadzenia. Książki miały bowiem służyć członkom konwentu w ich pracy duszpasterskiej i kształceniowej. Znaki i noty proweniencyjne pokazują wcześniejszych właścicieli poszczególnych egzemplarzy i sposoby gromadzenia, a ślady użytkowania rzeczywistych czytelników. Są istotnym przyczynkiem do odtworzenia tego rozproszonego księgozbioru.
\end{abstract}

Słowa kluczowe: książka; stary druk; biblioteka; dominikanie; Wilno; Książnica Zamojska

$* * * * *$

Poznanie dziejów kultury książki w Rzeczypospolitej Obojga Narodów wymaga badań podejmujących zagadnienie księgozbiorów historycznych. Eksploracje badawcze w tym obszarze, prowadzone zarówno w oparciu o źródła dokumentacyjne (inwentarze, spisy, testamenty), jak i kierujące uwagę na zachowane egzemplarze, należące do różnych zasobów bibliotecznych, pokazują, jak ważne przynoszą one korzyści naukowe w zakresie różnych dyscyplin. Warto je zatem kontynuować i pogłębiać, tym bardziej że wiele tego rodzaju zbiorów w dalszym ciągu pozostaje nierozpoznanych. Do tej grupy należą księgozbiory klasztorne wielu zgromadzeń, których domy gęstą siecią pokrywały terytorium dawnej Rze-

\footnotetext{
* Maria Juda - prof. dr. hab., Instytut Nauk o Kulturze, Wydział Filologiczny, Uniwersytet Marii Curie-Skłodowskiej e-mail: maria.juda@mail.umcs.pl https://orcid.org/0000-0001-7557-1850
} 
czypospolitej. W tym kontekście warto przyjrzeć się również bibliotekom dominikańskim. Dotychczasowy stan badań pokazuje, że nie tylko nie powstało monograficzne opracowanie ich księgozbiorów, ale dalekie są do poznania także biblioteki poszczególnych klasztorów, chociaż w ostatniej dekadzie nastąpił znaczący postęp ${ }^{1}$. Wiele klasztornych księgozbiorów historycznych wymaga dalszego badania, czy to z uwagi na pozyskane nowe źródła, czy na zastosowanie nowych metod, technik i narzędzi badawczych. Do tej kategorii należy m.in. księgozbiór dominikanów wileńskich, którego fragment przechowywany jest w zbiorach Książnicy Zamojskiej im. Stanisława Kostki Zamoyskiego. Kierowano na niego uwagę, ale dotychczasowe prace ograniczały się raczej do działań rejestracyjnych niż do bardziej pogłębionej analizy bibliologicznej, zwracającej uwagę na zagadnienia odnoszące się do produkcji, rozpowszechniania i użytkowania książki². Wymagają również uzupełnienia i weryfikacji wielu ustaleń poprzez wykorzystanie nowych, często globalnych źródeł informacjỉ ${ }^{3}$ Książka, jej ludzie i instytucje są faktem historycznym, dlatego wymagają one badania w kontekście wielu zjawisk o charakterze politycznym, społecznym, wyznaniowym, kulturalnym. Stąd też w eksploracjach dotyczących dziejów księgozbiorów historycznych, nawet w cząstkowym wymiarze, należy zwrócić uwagę na genezę i kierunki rozwoju instytucji, które je tworzyły, utrzymywały i rozwijały, oraz ludzi mających wpływ na ich charakter i korzystających z ich zasobów ${ }^{4}$.

Zakon dominikański, którego założycielem był św. Dominik Guzman, został powołany przez papieża Honoriusza III na mocy bulli Religiosam vitam, ogłoszonej 22 grudnia 1216 r. oraz breve z 21 stycznia 1217 r. ${ }^{5}$ Szybki rozwój zakonu zbiegł się $\mathrm{w}$ czasie $\mathrm{z}$ ostatecznym ustanowieniem jego budowy organizacyjnej, dokonanym na dwóch kolejnych kapitułach generalnych, które odbyły się w Bolonii w latach 1220 i 1221. Przeprowadzono również podział zgromadzenia na osiem prowincji i uchwalono jednolite ustawy zakonne.

Przyjęte jeszcze za życia założyciela podstawowe rozwiązania organizacyjne zapewniły wspólnocie dominikańskiej jednolitość i trwałość na stulecia. Ustrój zakonu umiejętnie łączył elementy tradycji monastycznej z wymogami czasów i specjalnym charakterem zgromadzenia, który polegał na zaakceptowaniu głównego posłannictwa, czyli kaznodziejstwa pojętego jako nauczanie prawd chrześci-

${ }^{1}$ Zob. pw.kasaty.pl (dostęp: 10.09.2019); M. Miławicki, Inwentarze i spisy klasztorów dominikańskich skasowanych w guberniach zachodnich Cesarstwa Rosyjskiego w XIX w. Stan źródet i miejsca ich przechowywania, „Haereditas Monasteriorum”, 1 (2012) s. 141-172; T. Stolarczyk, Analecta Dominiciana. Szkice z dziejów Zakonu Braci Kaznodziejów w Polsce Środkowej (XIII-XVIII wiek), Wieluń 2016 (tam też literatura przedmiotu).

2 Zob. I.M. Kozłowska, Starodruki z biblioteki O.O. Dominikanów z Wilna w Bibliotece im. H. Łopacińskiego w Lublinie, Lublin 1999 [praca magisterska, Archiwum UMCS].

${ }^{3}$ Worldcat, https://www.worldcat.org (dostęp: 03.09.2019).

${ }^{4}$ Zob. K. Migoń, Bibliologia-nauka o kulturze ksiązki, w: Encyklopedia ksiażki, red. A. Żbikowska-Migoń, M. Skalska-Zlat, t. 1: Eseje·A-J, Wrocław 2017, s. 23-32.

${ }^{5}$ J. Kłoczowski, Dominikanie, w: Encyklopedia katolicka, t. 4, red. R. Łukaszyk, L. Bieńkowski, F. Gryglewicz, Lublin 1985, kol. 69. 
jańskich w celu nawrócenia chrześcijan i niewierzących na drogę świadomego życia wiarą chrześcijańską.

Charakter żebraczy zakonu zmuszał jego członków do osiedlania się w dużych miastach, gdyż tylko liczne i bogate skupiska ludzkie mogły zabezpieczyć ludnym klasztorom, żyjącym w XIII wieku wyłącznie z jałmużny, wystarczające środki utrzymania. Każdy dom zakonny musiał mieć też zapewnioną, odpowiednią do podjęcia określonych zadań duszpasterskich, liczbę zakonników, czyli przynajmniej 12 braci. Nowością była również silna, scentralizowana władza generała oraz prowincje zarządzane przez prowincjała. Wszystkie władze zakonne wybierane były przez odpowiednie kapituły, ponadto każdy zakonnik składał przysięgę posłuszeństwa wobec generała ${ }^{6}$. Poparcie papieży dla zakonu, związanego ściśle z nakreślonym przez IV Sobór Laterański programem reformy Kościoła, zapotrzebowanie społeczne na jego działalność, precyzyjność ustaleń prawodawstwa, wysoki poziom intelektualny oraz otwarta postawa wobec potrzeb społeczeństwa zapewniły dominikanom popularność i rozwój. Na przełomie XIII i XIV stulecia zakon posiadał ok. 600 klasztorów z ponad 10000 zakonników?

Inicjatorem sprowadzenia Zakonu Kaznodziejskiego do Polski był bp krakowski Iwon Odrowąż $\dot{z}^{8}$ W 1223 r. powstał pierwszy dom zakonny w Krakowie, a w latach następnych w Sandomierzu, Wrocławiu, Gdańsku, Płocku i Kamieniu Pomorskim. W 1228 r. na kapitule generalnej w Paryżu utworzono polską prowincję dominikanów, obejmującą zasięgiem również Czechy i Morawy. W połowie XIII stulecia wszystkie diecezje polskie, z wyjątkiem lubuskiej, objęte zostały siecią klasztorów dominikańskich. Kiedy w 1301 r. utworzono osobną prowincję czeską, przy polskiej pozostały 32 klasztory męskie i 3 żeńskie, które obejmowały ziemie polskie ze Śląskiem, Pomorzem i Prusami. W XIV i XV wieku nowe fundacje w obrębie polskiej prowincji powstawały sporadycznie i lokowano je głównie na wschodnich ziemiach Rzeczypospolitej. W 1612 r. z 12 klasztorów wschodnich wyodrębniła się prowincja ruska z głównym ośrodkiem we Lwowie, a w 1647 r. na kapitule generalnej w Walencji kongregacja wileńska przekształcona została w prowincję wileńską, której centrum mieściło się w Wilnie9.

Początki obecności dominikanów w Wilnie nie miały trwałego charakteru. Prawdopodobnie pojawili się za panowania Giedymina, by po krótkim pobycie opuścić miasto $^{10}$. Niedługo trwała również misja kilku zakonników za czasów Wła-

${ }^{6}$ J.A. Spież, Dominikanie w Polsce, w: Chrześcijańska odpowiedź na pytanie człowieka. W 750-lecie stużby polskich dominikanów Bogu i ludziom, Warszawa 1974, s. 10.

${ }^{7}$ J. Kłoczowski, Wspólnoty chrześcijańskie. Grupy życia wspólnego w chrześcijaństwie zakonnym od starożytności do XV wieku, Kraków 1964, s. 316.

${ }^{8}$ C. Deptuła, Iwon Odroważ, biskup, zm. 20 lub 21 VIII 1229, w: Encyklopedia katolicka, t. 7, red. S. Wielgus, Lublin 1977, kol. 579-580.

${ }^{9}$ Spież, Dominikanie w Polsce, s. 11-13.

${ }^{10}$ Podstawowe źródło informacji o pobycie i działalności dominikanów w Wilnie, zob. Lietuvos Valstybės Istorijos Archywas (LVIA), sygn. F.1135-8-10. Archiwum historyka Władysława Zahorskiego; zob. też Kozłowska, Starodruki z biblioteki, s. 40-48; S. Brzozecki, Litewska prowincja dominikanów, w: Dominikanie-Gdańsk-Polska-Europa: materiały z konferencji międzynarodowej, red. D.A. Dekański, A. Gołembik, M. Grubka, Gdańsk 2003, s. 140. 
dysława Jagiełly. Na stałe zadomowili się w stolicy Wielkiego Księstwa Litewskiego w 1501 r. Akt fundacyjny wystawił 8 maja Aleksander Jagiellończyk, a świadkami tego wydarzenia byli m.in. bp wileński Wojciech Tabor ${ }^{11}$, a także wojewoda wileński Mikołaj Radziwiłłowicz ${ }^{12}$ oraz kasztelan wileński Aleksander Jurewicz Holszański ${ }^{13}$. Decyzję króla potwierdził bullą z dnia 23 czerwca 1501 r. papież Aleksander VI ${ }^{14}$. Zakonnicy otrzymali kościół Św. Ducha, którego początki sięgają panowania Władysława Jagiełły ${ }^{15}$, probostwo, kamienice, folwark, grunta stajenne, karczmę i jezioro Raszeytes. Nadania te i opieka królewska zapewniły dominikanom odpowiednie warunki do życia i działalności, co przyczyniło się do wzrostu liczby zakonników, przez co konwent wileński należał do pięciu największych w prowincji ${ }^{16}$. Dzielił historię stolicy Wielkiego Księstwa Litewskiego przez ponad 400 lat, ciesząc się szacunkiem i sympatią mieszkańców, uwidacznianą w licznych nadaniach, darowiznach i zapisach władców oraz możnych litewskich.

Historia nie była łaskawa dla klasztoru i kościoła Św. Ducha. Kilkakrotnie nawiedzały je pożary i działania wojenne, w efekcie których zakonnicy zmuszani byli do opuszczenia miasta i przeniesienia się do innych domów prowincji polskiej $^{17}$. W dziele odbudowy wspierali zakonników m.in. strażnik Wielkiego Księstwa Litewskiego Ludwik Pociej ${ }^{18}$ oraz Brygida z Radziwiłłów Sołłohubowa ${ }^{19}$. Dzięki ich staraniom ok. 1770 r. stanęła dzisiejsza świątynia wraz z budynkami klasztornymi.

Kres wileńskiemu konwentowi położyły władze carskie, nakazując w $1884 \mathrm{r}$. opuścić zakonnikom klasztor, przekształcając kościół w parafialny i oddając go

${ }^{11}$ P. Nitecki, Biskupi Kościoła w Polsce w latach 965-1999. Stownik biograficzny, Warszawa 2000, s. 443.

${ }^{12}$ Akta unji Polski z Litwa, 1385-1791, wyd. S. Kutrzeba, W. Semkowicz, Kraków 1932, s. 127.

${ }^{13}$ S.M. Kuczyński, Holszański Aleksander Jurewicz, h. Hippocentaurus (zm. 1511), ksiaże litewski, kasztelan wileński, w: Polski stownik biograficzny, t. 9, red. K. Lepszy, Wrocław 1960, s. 586587.

${ }^{14}$ Podręczna encyklopedia kościelna, t. 9-10, red. Z. Chełmicki, Warszawa 1906, s. 90.

${ }_{15} \mathrm{~J}$. Garniewicz, Świątynie wileńskie od czasów najdawniejszych do obecnych, KędzierzynKoźle 1993, s. 89; B. Orszewska, Klejnoty wileńskie, Wilno 2002, s. 14.

${ }_{16} \mathrm{~J}$. Kłoczowski, Zakon dominikański i początki wyższego szkolnictwa na ziemiach polskich, w: Dominikanie-Gdańsk, s. 70.

${ }^{17}$ Zob. B.B. Jachimowicz, Relacja o (...) upadku miasta wileńskiego (...), [Wilno] 1748; tenże, Światto okropne (...) pożar (...) miasta wileńskiego (...), [Wilno] 1748; O pożarze tym pisał też o. Wojciech Bagiński, zob. Rękopism X. Bagińskiego, Dominikanina Prowincji Litewskiej (17471784), wyd. E. Tyszkiewicz, Wilno 1854, s. 8-9; E. Tyszkiewicz, O klasztorach zgromadzeń istniejacych obecnie w diecezji Wileńskiej: Dominikanie, „Teka Wileńska”, 3 (1859) s. 255 i nast.; J.I. Kraszewski, Wilno od początków jego do roku 1750, t. 2, Wilno 1842, s. 41; J.M.A. Giżycki, Wiadomości o dominikanach prowincji litewskiej, cz. 1, Kraków 1917, s. 253.

${ }^{18}$ Z. Zielińska, Pociej Ludwik, h. Waga (ok. 1726-1771), strażnik litewski, w: Polski słownik biograficzny, t. 27, red. E. Roztworowski, Wrocław 1983, s. 47-49.

${ }_{19}^{19}$ P.P. Romaniuk, Sołłohub Antoni Józef, h. Prawdzic, zm. 1759, generał artylerii litewskiej, w: Polski stownik biograficzny, t. 40, red. H. Markiewicz, Warszawa 2000, s. 306-308. 
w zarząd duchowieństwu diecezjalnemu. Bracia zakonni zostali przeniesieni do innych klasztorów, a wileński konwent przeszedł na własność miasta ${ }^{20}$.

Postanowienia zawarte w konstytucjach Zakonu Kaznodziejskiego zobowiązywały każdego dominikanina do wykorzystania wolnej chwili na pogłębianie wiedzy o Bogu. Od samego początku uwidoczniły się też silne tendencje i dążenia do związania zgromadzenia z myślą uniwersytecką, szczególnie teologiczną. Każdy klasztor dominikański był jednocześnie szkołą, która prowadzona była przez wykształconego lektora, mającego za sobą co najmniej czteroletnie wyspecjalizowane studia teologiczne. Obowiązek kształcenia się obejmował wszystkich obecnych w danym klasztorze braci, zajęcia odbywały się codziennie po mszy konwentualnej i polegały na ćwiczeniach scholastycznych, podobnych do uniwersyteckich, a więc na lekturze i dysputach. Zakazane było tworzenie nowych klasztorów bez wyspecjalizowanych lektorów - teologów ${ }^{21}$.

Działania w obszarze szkolnictwa doprowadziły do tego, że dominikanie stali się rodzajem międzynarodowej organizacji szkolnej z kompletnym systemem szkół różnego stopnia i zakresu działania, o jednolitym, ustalonym przez władze generalne, programie. Przy każdym klasztorze musiała istnieć szkoła teologiczna dla wszystkich znajdujących się w nim zakonników, którą prowadził wykształcony lektor. Zapewniała ona podstawową edukację wszystkim członkom konwentu, była też otwarta na potrzeby duchowieństwa świeckiego. Dla młodych profesorów zakonnych tworzono studia atrium, dające podstawową wiedzę o kulturze scholastycznej oraz specjalne studia teologiczne dla kapłanów zakonnych. W każdej prowincji istnieć musiały też tzw. studia solemne. Przygotowywały one nauczycieli teologii (lektorów) do wypełniania szczególnie ważnych i odpowiedzialnych zadań, wynikających z fundamentalnych założeń zakonu. Najbardziej rozwinięte w obrębie zgromadzenia studia solemne uzyskiwały status studiów generalnych, otwartych dla zakonników ze wszystkich prowincji. To głównie w nich formowano intelektualną elitę zakonu ${ }^{22}$. Najczęściej opierały się na uniwersytetach i ich wydziałach teologicznych. Już na początku XIV wieku przyjęto zasadę, że każda prowincja zakonna powinna posiadać własne studium generalne. Największe z nich, funkcjonujące w Paryżu, Montpellier, Oksfordzie, Bolonii, Padwie czy Kolonii, przeznaczone były do zaspokajania potrzeb wszystkich prowincji ${ }^{23}$.

Dominikański system szkolny w Polsce nie odbiegał od modelu ogólnozakonnego. Zgodnie z ogólnymi założeniami każdy klasztor połączony był ze szkołą, w której zakonnik miał pogłębiać swoją wiedzę teologiczną. Konwent przyjmował nowicjuszy i zobowiązany był do stworzenia dla nich odpowiedniej szkoły. W każdym klasztorze było więc dwuletnie studium gramatyki, mające zapewnić dobrą znajomość łaciny w mowie i piśmie. Później następowały studia logiki i re-

${ }^{20}$ LVIA, sygn. F.1135-8-10. Archiwum historyka Władysława Zahorskiego, s. 97.

${ }^{21}$ Kłoczowski, Wspólnoty chrześcijańskie, s. 283, 329.

${ }^{22}$ J. Kłoczowski, Dominikanie w środkowo-wschodniej Europie i ich kultura intelektualna oraz pastoralna w wiekach średnich, w: Dominikanie w Europie XII-XV wieku: aktywność duszpasterska i kultura intelektualna, red. J. Kłoczowski, J.A. Spież, Poznań 2002, s. 158-159.

${ }^{23} \mathrm{~J}$. Kłoczowski, Młodsza Europa. Europa środkowo-wschodnia w kręgu cywilizacji chrześcijańskiej średniowiecza, Warszawa 1998, s. 350-351. 
toryki oraz filozofia, której podstawy stanowiły traktaty Arystotelesa. Były one niezbędne przed podjęciem zasadniczych dla zakonu i jego funkcji studiów teologicznych, zgodnych z programem wydziału teologicznego uniwersytetu paryskiego. W zasadzie każde studium teologii, niezależnie od nazwy, realizowało ten sam, kilkuletni program i - przy oczywistych różnicach w poziomie - stanowiło wyższą szkołę teologiczną ${ }^{24}$. Studia generalne były szkołami wyższymi z prawem nadawania stopnia lektora teologii i przeprowadzania egzaminów na stopień bakałarza oraz magistra teologii dla zakonników posiadających promocję od generała zakonu lub kapituły generalnej ${ }^{25}$.

Dominikanie wileńscy wkrótce po ustanowieniu placówki zaczęli prowadzić studia partykularne. Wśród uczących się była nie tylko miejscowa młodzież zakonna, ale też z kilku sąsiadujących klasztorów ${ }^{26}$. Po utworzeniu prowincji litewskiej powołano do życia studia generalne z dwoma wydziałami: filozofii i teologii, legitymującymi się pełnymi prawami akademickimi należnymi tego rodzaju instytucjom $^{27}$. Bogaty program kształcenia, obejmujący filozofię, geometrię, matematykę, teologię, historię Kościoła, Pismo Święte i języki nowożytne (francuski i niemiecki), a od XVIII wieku także architekturę ${ }^{28}$, sprawiał, że korzystano też z wykładów Akademii Wileńskiej. Zdolni studenci-zakonnicy wyjeżdżali na naukę do licznych krajów zachodnioeuropejskich ${ }^{29}$, zdobywając wiedzę i doświadczenie, które wykorzystywali do podniesienia jakości i uatrakcyjnienia duszpasterstwa wiernych.

Tak zorganizowany system szkolnictwa stanowił niewątpliwie podstawową pomoc $\mathrm{w}$ działalności kaznodziejskiej i duszpasterskiej braci, ale by mógł właściwie spełniać swoją rolę, niezbędna była również biblioteka, stanowiąca warsztat pracy dla lektora i posiadająca zbiór różnorodnych pomocy naukowych dla ogółu zakonników. Zgodnie z ustawodawstwem zakonnym każdy klasztor dominikański powinien posiadać wydzielone miejsce, służące do przechowywania książek przeznaczonych do użytku przez wszystkich zamieszkałych w nim braci ${ }^{30}$. W średniowieczu miał też posiadać własne skryptorium, w którym kopiści przepisywali potrzebne teksty. Biblioteki dominikańskie należały do najzasobniejszych książnic klasztornych. Także konwenty w polskiej prowincji, w Krakowie czy Wrocławiu, legitymowały się księgozbiorami zaliczanymi do największych w kraju. Ich przeło-

${ }^{24}$ Kłoczowski, Zakon dominikański, s. 72-73, 77.

${ }^{25}$ Spież, Dominikanie w Polsce, s. 18-19.

${ }^{26}$ R. Świętochowski, Szkolnictwo teologiczne dominikanów, w: Dzieje teologii katolickiej w Polsce, red. M. Rechowicz, t. 2: Od Odrodzenia do Oświecenia, Lublin 1975, s. 253-254; Kozłowska, Starodruki z biblioteki, s. 51-53.

${ }^{27}$ Studia generalne funkcjonowały w latach 1644-1864, zob. Świętochowski, Szkolnictwo teologiczne, s. 214.

${ }^{28}$ Świętochowski, Szkolnictwo teologiczne, s. 214; M. Morelowski, Znaczenie baroku wileńskiego XVIII stulecia, Wilno 1940, s. 29.

${ }^{29}$ Świętochowski, Szkolnictwo teologiczne, s. 219.

${ }^{30}$ Constitutiones, declarationes et ordinationes capitulorum generalium Sacri Ordinis Fratrum Praedicatorum ab anno 1220 usque ad 1650 emantae, Prima pars tables, red. V. Fontana, Romae 1862, s. 42. 
żeni mieli dbać nie tylko o studia i usilnie je popierać, ale też zapewnić braciom wszelkie pomoce i warunki potrzebne do nauki. Niebagatelną rolę w tym względzie odgrywało wyposażenie biblioteki w potrzebne książki oraz przeznaczanie co roku odpowiednich środków na uzupełnienie księgozbioru. To, jak wywiązywali się z tych obowiązków, podlegało dodatkowo kontroli prowincjała w czasie wizytacji kanoniczych ${ }^{31}$. W realizacji tych zadan istotną rolę odgrywał bibliotekarz i z tego względu na to stanowisko powoływano zakonników wykształconych i szanowanych ${ }^{32}$.

Początki biblioteki klasztoru Św. Ducha w Wilnie sięgają zapewne momentu jego fundacji w $1501 \mathrm{r}$. Nie są wprawdzie znane źródła potwierdzające ten fakt, ale $\mathrm{z}$ uwagi na to, że obowiązujące przepisy zakonne nie pozwalały na zakładanie nowej placówki bez lektora, można wnioskować, iż dominikanie posiadali już wtedy księgozbiór, tym bardziej że w konwencie wileńskim był zakonnik wypełniający powyższą rolę ${ }^{33}$.

Trudno określić lokalizację biblioteki w budynku klasztornym. Z uwagi na zwyczaje panujące nie tylko $\mathrm{w}$ różnych konwentach dominikańskich, lecz także w innych zgromadzeniach, książki mogły być przechowywane i udostępniane w jednej z cel nad refektarzem, przy dormitorium lub nad skryptorium (jeśli istniało). Dbano, aby biblioteka była oddalona od wilgotnych pomieszczeń oraz grożących zaprószeniem ognia. Zdarzało się też, że lokowano ją w budynkach poza obrębem zabudowań klasztornych. Zawsze jednak dokładano starań, by spełnione były warunki nakreślone $\mathrm{w}$ dominikańskich przepisach bibliotecznych, opartych na zwyczajach kanoników regularnych św. Wiktora w Paryżu z lat 1113-1135, rozwiniętych później przez generała zakonu Humberta de Romanis w drugiej połowie XIII wieku w dziele De vita regularii ${ }^{34}$.

Dane dotyczące miejsca biblioteki w wileńskim klasztorze pochodzą z drugiej połowy XVIII wieku. Książnica mieściła się wówczas na drugim piętrze, w obszernej sali z dużymi oknami i sufitem pokrytym freskami. Na tym samym poziomie znajdowały się też cele zakonne, cele nowicjatu i jego biblioteka, mieszkanie przeora, refektarz i apteka ${ }^{35}$.

W trzynastym rozdziale dzieła Humberta de Romanis pod tytułem De officio librarii widnieją zapisy odnoszące się do pracy librariusa, biblioteki oraz form i za-

${ }^{31}$ Ksiega konstytucji i zarządzeń Zakonu Braci Kaznodziejów: statut polskiej prowincji Zakonu Braci Kaznodziejów, oprac. P. Krzysztofiak, tłum. J. Janczak, M. Wylęgała, Warszawa 1996, s. 3536.

${ }^{32}$ I. Szostek, Biblioteka dominikanów lwowskich w świetle katalogu z roku 1776, w: Studia nad historia dominikanów w Polsce 1222-1972, red. J. Kłoczowski, Warszawa 1975, s. 441.

${ }_{33}$ J. Kłoczowski, Dominikanie polscy na Śląsku w XIII-XIV wieku, Lublin 1956, s. 215; P. Kielar, Organizacja szkolnictwa dominikańskiego w XIV wieku, „Studia Philosophiae Christianae”, 5 (1969) s. 308.

${ }^{34}$ K. Zawadzka, Biblioteka klasztoru dominikanów we Wroctawiu (1226-1810), w: Studia nad historia, s. 298.

${ }^{35}$ LVIA, sygn. F.1135-8-10, Archiwum historyka Władysława Zahorskiego, s. 97; Kozłowska, Starodruki z biblioteki, s. 54. 
sad korzystania z księgozbioru klasztornego ${ }^{36}$. Bibliotekarz miał zatem troszczyć się o odpowiednie warunki przechowywania książek (zabezpieczenie przed deszczem, wilgocią i pleśnią, zapewnienie dopływu świeżego powietrza, a także odpowiednio oznakowane szafy). Powinien też pilnować klucza do pomieszczeń bibliotecznych i udostępniać książki w określonym czasie. Do jego zadań należało również sukcesywne spisywanie książek (aktualny spis miał przekazywać swojemu następcy) oraz ustalanie zasad ich gromadzenia i usuwania książek nieaktualnych lub zaczytanych. Dublety i dzieła rzadko czytane należało wystawiać na sprzedaż, a za uzyskane środki nabywać nowe, bardziej przydatne dla celów edukacyjnych i duszpasterskich. Co rok lub dwa lata należało przeprowadzać skontrum i przy tej okazji wyselekcjonować woluminy, które wymagały oczyszczenia i konserwacji. Podkreślano, że biblioteka powinna być wyposażona w pulpity i otwierana o ustalonych porach. Z książek należało korzystać na miejscu, na zewnątrz tylko za zgodą magistra studentów. Nie wolno też było robić prywatnych notatek na kartach książek, niszczyć ich czy źle się z nimi obchodzić. Na wyposażeniu biblioteki powinien być również inkaust, pióra, rysiki, linijki, nożyki do zacinania piór, kreda itp. Pergamin można było otrzymać za zezwoleniem przełożonego, ale tylko do notowania wykładów, dysput czy notatek z lektury.

Najwcześniejszym znanym dokumentem informującym o zasobie wileńskiej biblioteki dominikanów jest inwentarz z pierwszej połowy XVII wieku, zawierający spis 506 pozycji wydawniczych, należących prawdopodobnie do księgozbioru podręcznego ${ }^{37}$. Z dotychczasowych badań wynika, że podobnie jak wiele bibliotek tego zakonu wileńska książnica była bogata w literaturę niezbędną dla celów naukowych, dydaktycznych i duszpasterskich braci zakonnych. Wiktor Wittig podaje, że w 1655 r. biblioteka liczyła 5317 tomów ${ }^{38}$. Znaczna jej część zniszczona została w czasie pożaru w 1748 r. oraz przez wojska francuskie w 1812 r. ${ }^{39}$ Władysław Zahorski zauważa, że księgozbiór liczył ponad 5000 dzieł ${ }^{40}$, a Józef Ignacy Kraszewski podaje liczbę ponad $6000^{41}$. Obaj nie precyzują jednak, z jakiego okresu te dane pochodzą. Kolejny badacz, Franciszek Radziszewski, najpierw odnotowuje liczbę ponad 6000 woluminów ${ }^{42}$, by później określić zasobność biblioteki w $1842 \mathrm{r}$. na 5300 tomów ${ }^{43}$.

${ }^{36}$ Szostek, Biblioteka dominikanów, s. 412-413.

${ }^{37}$ Archiwum OO. Dominikanów w Krakowie (ADKr), sygn. I.c.III 76/252, Teka wileńska; M. Juda, Kultura intelektualna i duchowa dominikanów wileńskich $w$ świetle inwentarza biblioteki z I połowy XVII wieku, „Archiwa, Biblioteki i Muzea Kościelne”, 114 (2020) s. 123-143.

${ }^{38}$ W. Wittig, Ex-librisy bibliotek polskich XVII i XVIII wieku, Warszawa 1903, s. 18.

${ }^{39}$ LVIA, sygn. F.1135-8-10. Archiwum historyka Władysława Zahorskiego, s. 97; F. Radziszewski, Wiadomość historyczno-statystyczna o znamienitszych bibliotekach $i$ archiwach publicznych i prywatnych tak niegdyś bytych jako i obecnie istniejacych w krajach dawna Polska składajacych, a mianowicie: w Królestwie Polskiem, Galicyi W.Ks. Poznańskiem i Zachodnich guberniach Państwa Rossyjskiego porząkiem abecadłowym miejsc ułożona, Kraków 1875, s. 112.

${ }^{40}$ LVIA, sygn. F.1135-8-10, Archiwum historyka Władysława Zahorskiego, s. 97; Podręczna encyklopedia, s. 90.

${ }^{41}$ J.I. Kraszewski, Wilno od początków jego do roku 1750, t. 4, Wilno 1842, s. 82.

${ }^{42}$ Radziszewski, Wiadomość historyczno, s. 112.

${ }^{43}$ Tamże, s. 112; Miławicki, Inwentarze i spisy, s. 147. 
Po likwidacji w 1844 r. wileńskiego klasztoru dominikanów księgozbiór uległ rozproszeniu. Większość książek włączona została do miejscowej Biblioteki Seminaryjnej i Publicznej ${ }^{44}$, ale niektóre znalazły miejsce w kolekcjach zakonnych i prywatnych. Stosunkowo niewielka jego część trafiła do rąk związanego ze środowiskiem wileńskim bibliografa i bibliofila Władysława Trębickiego ${ }^{45}$. Wszystkie książki opatrzył swoim imieniem i nazwiskiem „Władysław Trębicki” w pełnym lub skróconym brzmieniu. Wiele egzemplarzy oznaczył małymi gwiazdkami u góry karty tytułowej, uzupełniał brakujące karty tytułowe oraz umieszczał uwagi dotyczące unikatowości bibliograficznej wydania. Były precyzyjne i poprawne, co niewątpliwie świadczy o znakomitych kompetencjach bibliograficznych i bibliofilskich. Wiedzę i umiejętności w tym zakresie zdobywał, współpracując z wileńską firmą wydawniczo-księgarską Józefa i Adama Zawadzkich, Adamem Jocherem, ks. Michałem Bobrowskim, Józefem Ignacym Kraszewskim.

W 1861 r. księgozbiór Władysława Trębickiego nabyła Biblioteka Ordynacji Zamoyskich, która w swoich zasobach posiadała już dzieła z wileńskiej biblioteki dominikańskiej. Woluminy z kolekcji bibliofila ulokowano w Klemensowie. W 1956 r. znalazły się w zbiorach Wojewódzkiej Biblioteki Publicznej im. Hieronima Łopacińskiego w Lublinie ${ }^{46}$. W maju 2008 r. przejęła je w depozyt Książnica Zamojska im. Stanisława Kostki Zamoyskiego ${ }^{47}$.

Kolekcja klemensowska liczy 92 pozycji bibliograficznych. Nie wszystkie jednostki są w dobrym stanie fizycznym. Pozbawionych kart początkowych jest bowiem 23, a kart końcowych nie posiada 10 woluminów. Z tego też względu pojawiają się problemy z ustaleniem wszystkich danych bibliograficznych. Z ogólnej liczby 92 wydawnictw 63 opatrzonych jest miejscem i rokiem wydania, 4 druki posiadają tylko miejsce wydania, 2 tylko rok, a 18 pozbawionych jest obu elementów. Druków niezidentyfikowanych pod względem miejsca wydania jest 5, a roku wydania 10. Za najstarszy druk należy uznać dzieło rzymskiego poety okresu augustowskiego Publiusza Owidiusza Nazo Metamorphoseon, opublikowane po 13 stycznia $1534 \mathrm{r}^{48}$ Wytworami oficyn położonych na terytorium dawnej Rzeczypospolitej są 23 druki, pozostałych 64 jest dziełem warsztatów zagra-

${ }^{44}$ Wittig, Ex-librisy bibliotek, s. 18; E. Chwalewik, Zbiory polskie: archiwa, biblioteki, gabinety, galerje, muzea i inne zbiory pamiątek przeszłości w ojczyźnie i na obczyźnie, t. 2, Warszawa-Kraków 1927, s. 483.

${ }^{45}$ M. Łuszczyńska, M. Szwarc, Wtadystaw Trębicki zapomniany bibliofil i bibliograf XIX wieku, „Bibliotekarz Lubelski”, (1959) nr 4, s. 17-25; M. Łuszczyńska, Trębicki Władysław (1806-1861), ziemianin, oficer wojsk Królestwa Polskiego, historyk literatury, bibliofil, bibliograf, w: Stownik pracowników książki polskiej, red. I. Treichel, Warszawa 1972, s. 909; Kozłowska, Starodruki z biblioteki, s. 143.

${ }^{46}$ C. Nieścior, Księgozbiór klemensowski w Bibliotece im. H. Łopacińskiego, „Bibliotekarz Lubelski”, (1959) nr 1-2, s. 6-8.

${ }^{47}$ Księgozbiór klemensowski jest dostępny w wersji cyfrowej w: Książnica Zamojska im. Stanisława Kostki Zamoyskiego w Zamościu, www.biblioteka.zamosc.pl; cyfrowa.biblioteka.zamosc. $\mathrm{pl} /$ dlibra/collectiondescription?dirids=4 (dostęp: marzec 2019-styczeń 2020).

${ }^{48}$ Naso Publius Ovidius, In P. Ovidii Metamorphosin Henrici Glareani Annotationes haud uulgares..., Basileae, [Henricus] Petrus, 1534; Publiusz Owidiusz Nazo, (43 p.n.e. - 17 lub 18 n.e.), zob. M. Cytowska, H. Szelest, Literatura rzymska. Okres augustowski, Warszawa 1990, s. 412-568. 
nicznych. Najwięcej jednostek (11) opublikowała wileńska drukarnia jezuicka, 6 oficyny krakowskie, po 2 pracujące w Kaliszu i Połocku, po 1 w Warszawie i Sandomierzu. Z 64 wydawnictw zagranicznych najwięcej pochodzi z Niemiec (33) i jest wytworem drukarni zlokalizowanych w 14 ośrodkach wydawniczych, m.in. we Frankfurcie nad Menem, Kolonii, Lipsku, Norymberdze i Dillingen. Drugą pod względem liczebności grupą są wydawnictwa włoskie (9), a najwięcej z nich (4) w adresie wydawniczym posiada Wenecję. Po sześć druków pochodzi z Francji i Austrii, cztery z Holandii, po dwa ze Szwajcarii i Hiszpanii, po jednym z Belgii i Rosji. XVI-wiecznych edycji jest 8 , XVII-wiecznych 30, a XVIII-wiecznych 44. Zdecydowana większość pozycji (69) reprezentuje wydanie z określonego roku (w 3 przypadkach mamy do czynienia z podwójnymi egzemplarzami), jedna reprezentowana jest przez 4 wydania, przez 3 i przez 2 edycje ${ }^{49}$.

Księgozbiór zgromadzony w bibliotece konwentu wileńskiego służył nie tylko zakonnikom, ale również młodzieży studiującej w Wilnie. Musiał więc spełniać zasadnicze i podstawowe cele, dla których powołano bibliotekę. Pierwszym z nich była pomoc w pracy duszpasterskiej, ze szczególnym uwzględnieniem kaznodziejstwa, drugim - umożliwienie i ułatwienie kształcenia młodzieży zakonnej i pracy umysłowej (na dziewięciu woluminach widnieje informacja, że znajdowały się one w bibliotece nowicjatu) ${ }^{50}$. Dodatkowym zadaniem, wynikającym z reguły zakonnej zobowiązującej braci do czytania, było dostarczenie lektury do

${ }^{49}$ Por. Kozłowska, Starodruki z biblioteki, s. 152, 158-159.

${ }^{50}$ Ambrosius Calepinus, Passerati, sive lingvarum novem. Romanae, graecae, ebraicae, gallicae, italicae, gemanicae, hispanicae, anglicae, belgicae dictionarium, Lugduni Batavorum, ex officina redidiva Abrahami Cammelini, [ca. 1655]; A. Calepinus (1435-1510), włoski humanista, zob. S. Urbańczyk, Stowniki, ich rodzaje i użyteczność, [Wrocław] 1964, s. 12; Antoine Goudin, Philosophia iuxta inconclusa tutissimague divi Thomas dogmata..., Venetiis, Typis Dominici Lovisa, 1729. Antoine Goudin żył w 1. 1639-1695, zob. Goudin, Antoine, Encyclopedia.com, https://www.encyclopedia.com/religion/encyclopedias-almanacs-transcripts-and maps/goudin-antoine (dostęp: 23.01.2020); Nicolas Louis de Lacaille, Lectiones elementares algebrae et geometriae..., Vilnae, Typis S.R.M. et Reip[ublicae] Academ[iae] Soc. Jesu, 1733; Nicolas L. de Lacaille, francuski astronom (17131762), zob. J.S. Glass, Nicolas - Louis de La Caille, Astronomes and Geodesist, Oxford 2013; Giovanni Domenico Musanti, Fax chronologica ad omnigenam historiam..., Sandomiriae, [br.druk. Coll. Soc. Jesu] 1724; Jakub Nakcyanowicz, Praelectiones mathematicae ex Wolfianis elementis adornatae, Vilnae, Typis S.R.M. Academicis, 1761; Nakcjanowicz (Nakcyanowicz) Jakub, w: Encyklopedia wiedzy o jezuitach na ziemiach Polski i Litwy 1564-1995, oprac. L. Grzebień SJ przy współpracy zespołu jezuitów, Kraków 2004, s. 450; Diego de Zuniga Ortiz, Cursus philosophicus angelico-tomisticus, t. 2. [Kempten], Typis Ducalis Monasterii Campiodonensis, Per Rudolphum Dreher, 1667; Diego O. de Zúñiga (1636-1680), hiszpański historyk, zob. Diego Ortiz de Zúñiga, Real Academia de la Historia, dbe.rah.es/biografias/7529/diego-ortiz-de-zuniga (dostęp: 26.01.2020); Jan Stefan Piasecki, Mówca polski albo supplement do tomu pierwszego mów sejmowych..., t. 2, Kalisz, Druk. Coll. Soc. Jesu, 1676; Antoni Adam Skorupski, Commentariurum philosophiae, logice scilicet metaphisicae phisicae..., Vilnae, Typis S.R.M. Academicis, 1755; Adrian Vlacq, Tabulae sinuum tangentium et secantium... Editio nova et emmendata a Johannae Jacobo Hentio, Francofurti et Lipsiae, Impensis Johanni Friedrici Fleischneri, 1757; Johann J. Hentsch, (1723-1764), niemiecki filozof i matematyk, professor matematyki na Uniwersytecie w Helmstedt, zob. The Bloomsbury Dictionary of Eighteenth-Century German Philosophers, red. H.F. Klemme, M. Kuehn, London 2016, s. 319-320; Adrian Vlacq (1600-1667), niderlandzki wydawca, autor tablic matem- 
wyboru pod kątem zainteresowań czytelników. Takie cele gromadzenia zdaje się potwierdzać analizowany fragment księgozbioru i jego struktura treściowa.

Znaczną część badanego fragmentu zasobu bibliotecznego stanowią dzieła filozoficzne. Uwagę zwracają komentarze i opracowania dzieł Arystotelesa ${ }^{51}$. Wśród nich można znaleźć nie tylko monumentalną kolońską edycję prac Stagiryty ${ }^{52}$ czy komentarze dominikanina, profesora filozofii i teologii na Uniwersytecie w Walencji Masiusa Didacusa do jego „Fizyki”53, lecz także pracę Karola Jezierskiego opublikowaną w Wilnie ${ }^{54}$. W bibliotece dominikańskiej nie mogło zabraknąć dzieł i komentarzy do nich św. Tomasza z Akwinu ${ }^{55}$. Jest zatem pierwszy tom trzeciej części Summy teologicznej w lejdejskiej edycji z $1663 \mathrm{r}^{56}$, mediolańskie wydanie jego traktatów filozoficznych ${ }^{57}$ i prace autorów wywodzących się z zakonu kaznodziejskiego poświęcone poglądom filozoficznym Akwinaty ${ }^{58}$. Do tego zestawu doliczyć należy dwa egzemplarze dzieła dominikańskiego filozofa i scholastyka Antoine Goudina $^{59}$ oraz pracę francuskiego teologa dominikańskiego, profesora teologii na Uniwersytecie w Padwie Pere Nicolau Arnu ${ }^{60}$.

Warto wspomnieć o pojawiającej się czterokrotnie pracy filozoficznej francuskiego filozofa i teologa Laurenta Duhana ${ }^{61}$ i o dwóch dziełach jezuity, profesora Uniwersytetu w Gratzu, autora podręczników fizyki - Leopolda Gottlieba Biwal-

atycznych, publikował tablice logarytmiczne, zob. E.M. Bruins, On the history of logarithms: Bürgi, Napier, Briggs, de Decker, Vlacq, Huygens, „Janus”, 67 (1980) s. 241-260.

${ }^{51}$ H. Podbielski, Arystoteles - życie i twórczość, w: Literatura Grecji starożytnej, red. A. Podbielski, t. 2: Proza historyczna, krasomówstwo, filozofia i nauka, literatura chrześcijańska, Lublin 2005, s. 661-726.

${ }^{52}$ Aristoteles, Commentarii Collegii Conimbricensis Societatis Jesu in quatuor libros De Coelo, Meteorologicos et Parva Naturalia Aristotelis..., Colloniae, Impensis Lazari Zetneri, 1596.

${ }^{53}$ Didacus Masius, Commentariorum In Vniversam Aristotelis Philosophiam ... Aristotelis, Colonie Agrippinae, Apud Conradi Butgenii Viduam, 1628. M. Didacus (1553-1608), zob. Masius, Didactus, CERL Thesaurs, https://data.cerl.org/thesaurus/cnp00991500 (dostęp: 23.01.2020).

${ }^{54}$ Karol Jezierski, Arystoteles sub auspicilis ... Josephi De Ekliis Hylzen ..., Vilnae, Typographia Academiae Societatis Jesu [1749].

${ }^{55}$ S. Brzozecki, M.R. Górniak, Tomasz z Akwinu (ur. 1224/25-1274), doktor Kościoła, filozof, w: Encyklopedia katolicka, t. 19, red. E. Gigilewicz, Lublin 2013, kol. 848-852.

${ }^{56}$ Thomas Aquinas, Summa totius theologiae S. Thomae Aquinatis..., Lugduni, Sumptibus Viduae Petri Bailly et Petri Bailly, 1663.

57 Thomas Aquinas, Totus doctrinae philosophicae compendiosa tractatio..., Mediolani [1693], Ex typographia Caroli Josephi Quinti.

${ }^{58}$ Ortiz, Cursus philosophicus...; Raymund Ortz, Ariadna thomistica Theseum ... seu Cursus philosophicus ..., [Br. m. dr., po 1673].

${ }^{59}$ Goudin, Philosophia iuxta inconclusa...

${ }^{60}$ Nicolau Arnu, Clipeus philosophiae Thomisticae..., Biteriis, Henricus Martel, 1672. Pere N. Arnu żył w 1. 1629-1692, zob. Pere Nicolau Arnu, Gran enciclopèdia catalana, https://www.enciclopedia.cat/ec-gec-0005305.xml (dostęp: 24.01.2020).

${ }^{61}$ Laurent Duhan, Philosophus in utramque partem..., [Br. m. dr.], Juxta Exemplar Parisiis, 1726; toż, Norimbergae, Impensa Joannis Georgii Lochneri, 1753 (2 egz.), toż, Venetiis, Apud Laurentium Basilium, 1768; J. Schmutz, Duhan Laurent (ok. 1656-1726), w: Dictionary of Seventeenth-Century French Philosophers, t. 1, red. L. Foisneau, London-New York 2008, s. 390-392. 
$\mathrm{da}^{62} . \mathrm{Z}$ potrzeb dydaktycznych $\mathrm{w}$ księgozbiorze znalazły się zapewne prace $\mathrm{z}$ zakresu logiki portugalskiego filozofa i teologa Alojzego Antoniego Vernei ${ }^{63}$ i jezuickiego matematyka i przyrodnika Karla Scherffera ${ }^{64}$.

W kształceniu i działalności członków zakonu kaznodziejskiego istotną rolę odgrywały teksty z zakresu sztuki głoszenia kazań. W badanym fragmencie księgozbioru widnieje praca franciszkanina Franciszka Rychłowskiego, który znany jest nie tylko jako autor licznych dzieł kaznodziejskich i utworów panegirycznych, lecz także jako uczestnik kapituł generalnych w Rzymie i Hiszpanii ${ }^{65}$. Do tej grupy książek należy również Dzieło zbawienia ludzkiego Antoniego Stefanowicza ${ }^{66}$.

Znaczącą część badanego fragmentu księgozbioru stanowią dzieła historyczne, wśród których dominują prace starożytnych historiografów. W dwóch egzemplarzach występuje dzieło rzymskiego senatora i konsula, tworzącego za czasów Tyberiusza, Kaliguli i Trajana pisarza oraz historyka Kwintusa Kurcjusza Rufusa o czynach Aleksandra Wielkiego ${ }^{67}$, praca rzymskiego historyka i biografa Gajusza Swetoniusza Trankwillusza ${ }^{68}$, zapomniane w starożytności, a odkryte dla współczesnych w 1515 r. dzieło poświęcone historii Rzymu Wellejusza Paterkulusa ${ }^{69}$, biografie wybitnych wodzów i mężów stanu Korneliusza Neposa ${ }^{70}$ oraz autora licz-

${ }^{62}$ Leopold Gottlieb Biwald, Phisica generalia Quam auditorum philosophiae accomodata..., Graecii [Graz?], Sumptibus Josephi Mauritii Lechner, 1768; Biwald, Phisica generalis quam auditorium philosophiae..., Graecii [Graz?], Sumptibus Josephi Mauritii Lechner, typis haeredum Widmanstadii, 1767; C. von Wurzbach, Biwald Leopold Gottlieb (1731-1805), w: Biographisches Lexicon des Kaiserthums Oesterreich, cz. 1, red. L.C. Zamarski, Wien 1856, s. 415.

${ }^{63}$ Aloysius Antonius Verneius, De Re logica libri sex..., Vilnae, Ex Typographeo S. R. M. et Reipublicae PP. Scholarum Piarum, 1766. Aloysius A.Vernejus żył w 1. 1713-1792, zob. Luís António Verney, Escritores Lusófonos, escritoreslusofonos.net/2018/11/23/luis-antonio-verney (dostęp: 24.01.2020).

${ }^{64}$ Karl Scherffer, Institutiones logice et metaphysicae..., Vindobonae, Typis Joannis Thomae Trattner, 1763. K. Scherffer żył w 1. 1716-1783, zob. Jesuitscience.net, jesuitscience.net/p/1009 (dostęp: 24.01.2020).

${ }^{65}$ Franciszek Rychłowski, Kazania Dwoiakie na Niedziele Całego Rokv..., W Krakowie, w Drukarni Dziedzicow Krzysztofa Schedla, po 1672; G. A. Wiśniowiecki, Rychłowski Franciszek (1611-1673), w: Polski stownik biograficzny, t. 33, red. H. Markiewicz, Wrocław 1991/1992, s. 386387.

${ }^{66}$ Antoni Stefanowicz, Dzieło zbawienia ludzkiego, Kraków, w drukarni Woyciecha Goreckiego, 1678 .

${ }^{67}$ Quintus Curtius Rufus, ... De rebus gestis Alexandrii Magni..., Amstelodami, Juxta exemplar Elsevirorum, 1690; Toż, Patavii, [b. druk.], 1755; J.R. Hamilton, The date of Quintus Curtius Rufus, „Zeitschrift für Alte Geschichte”, 37 (1988) s. 445-456; Cytowska, Szelest, Literatura rzymska. Okres cesarski, s. 223-236.

${ }^{68}$ Gaius Suetonius Tranquillus, ...Caesares: Obscuriorum locorum brevis..., Coloniae, Ioannes Gymnicus excudebant, 1539; Cytowska, Szelest, Literatura rzymska. Okres cesarski, s. 425-432.

${ }^{69}$ Caius Valleius Patercvlvs, Historiae Romanae libri duo..., Lugduni Batavorum, ex officina Elseviriana, 1639; S. Stabryła, Historia literatury starożytnej Grecji i Rzymu, Wrocław 2002, s. 432433.

${ }^{70}$ Cornelius Nepos, De vita excellentium imperatorum..., [Br. m. i r.dr.], po 1663; L. Winniczuk, Wstęp, w: Kornelisz Nepos, Żywoty wybitnych mężów, Warszawa 1974, s. 5-30. 
nych dzieł historycznych, gramatycznych i retorycznych Pliniusza Starszego ${ }^{71}$. Pojawia się również książka dotycząca dziejów Niemiec Leonarda Pappusa von Tratzberg ${ }^{72}$ oraz wielokrotnie wydawana praca niemieckiego teologa luterańskiego, profesora na Uniwersytecie w Wittenberdze Wolfganga Franza (Franziusa), które była adresowana do studiujących teologię oraz kaznodziejów ${ }^{73}$. Warto również wspomnieć o dwóch dziełach prawniczych - holenderskiego prawnika, profesora Uniwersytetu w Löwen Andrē Delvaux ${ }^{74}$ i Teodora Zawackiego ${ }^{75}$.

Kolejną wyróżniającą się grupę stanowią książki matematyczno-przyrodnicze i medyczne. Są wśród nich dzieła przede wszystkim autorów obcych, takich jak: Johann Christian Wolf ${ }^{76}$, Nicolas Louis de La Caille ${ }^{77}$ czy Johann Jacob Hentsch i Adrian Vlacq ${ }^{78}$, ale znaleźć można też polskiego jezuitę, kierownika wileńskiego obserwatorium astronomicznego Jakuba Nakcyanowicza ${ }^{79}$.

Znaczą część stanowią podręczniki szkolne, co zdaje się potwierdzać ożywioną pracę dydaktyczną dominikanów wileńskich i skupionego wokół nich licznego grona uczniów. Widnieją wśród nich prace i ćwiczenia z zakresu retoryki ${ }^{80}$, gramatyki języka łacińskiego ${ }^{81}$ i słowniki ${ }^{82}$.

${ }^{71}$ Caius Plinius Caecillius Secundus, Epistolarum libri decem..., Petropoli, Typis Academiae Imperialis Scientiarum, 1724; Cytowska, Szelest, Literatura rzymska. Okres cesarski, s. 355-359.

${ }^{72}$ Leonardus Pappus, Epitome rerum germanicarum ab anno 1617-1643 gestarum, [Br. m. dr.], 1643; F.X. von Wegele, Pappus Leonard (1607-1677), w: Allgemeine Deutsche Biographie, t. 25, Leipzig 1887, s. 164-165.

${ }^{73}$ Wolfgang Franzius, Animalium historia sacra ..., Amstelodami, Apud Joannem Janssonium, 1643; F.W. Bautz, Franz Wolfgang, w: Biographish-Bibliographisches Kirchenlexikon, t. 2, Hamm 1990, sp. 112.

${ }^{74}$ André Delvaux (1569-1636), zob. Delvaux, André, CERL Thesaurs, https://data.cerl.org/thesaurus/cnp01353402 (dostęp: 24.01.2020).

${ }^{75}$ André Delvaux, Paratitla, sive, Summaria et methodica explicatio Decretalium D. Georgii papae IX..., Lovanii, Apud C. Coenesteyium, 1640; Teodor Zawacki, Memoriale processus iudiciarii et flosculorum legume..., Cracoviae, Apud haeredes Iacobi Sybeneycher, 1623.

${ }^{76}$ Johann Christian Wolf, Cosmologia generalia metodo scientifica pertractata..., Francofurtii et Lipsiae, prostate in Officina Libraria Rengeriana, 1737; Johann Ch. Wolf, niemiecki filolog, hebraista, polihistor (1683-1739), zob. E. Jacobs, Wolf Johann Christian, w: Allgemeine Deutsche Biographie, t. 43, Leipzig 1898, s. 761.

${ }^{77}$ Lacaille, Lectiones elementares...

${ }^{78}$ Vlacq, Tabulae sinuum tangentium et secantium...

${ }^{79}$ Nakcyanowicz, Praelectiones mathematicae...

${ }^{80} \mathrm{~Np}$. Hermann Goldhagen, Rhetorica explicata et applicata ad eloquentiam civilem et ecclesiasticam..., Mannheimii, ex Typographejo Electorali Aulico, apud Nicolaum Pieron, 1753; Hermann Goldhagen (1718-1794), niemiecki teolog katolicki, zob. A.Ph. Brück, Goldhagen Herman, w: Neue Deutsche Biographie, t. 6, Berlin 1964, s. 605.

${ }^{81} \mathrm{~Np}$. Emmanuel Alvarez, De institutione grammatica libri tres, Calissi, [Typ. Coll. Soc. Jesu], 1760; Emmanuel Alvarez (1526-1582), jezuita portugalski, autor podręcznika gramatyki łacińskiej, zob. Encyklopedia wiedzy, s. 8.

${ }^{82} \mathrm{~Np}$. Calepinus, Passerati, sive lingvarum novem... 
O właścicielach i o losach książek analizowanego fragmentu księgozbioru wiele mówią znaki (ekslibrisy, superekslibrisy i pieczęcie) oraz noty proweniencyjne ${ }^{83}$. Ekslibrisami biblioteki opatrzonych jest 50 woluminów. Umieszczone są na wewnętrznej stronie przedniej okładziny. Mają one postać nalepki o wymiarach $48 \times 38$ $\mathrm{mm}$. W podwójnej prostokątnej obwódce liniowej widnieje napis BIBLIOTHECAE $\|$ CONVENTUS $\|$ GENERALIS || VILNENSIS SANCTI $\|$ SPIRITUS ORDINIS \| PRAEDICATORUM\|, który wytłoczony jest kapitałą. Innymi znakami wskazującym przynależność książki do określonego właściciela są pieczęcie. Na odwrocie karty tytułowej czterech pozycji widnieje pieczęć z inicjałami F.D.S. [Frater Dominicus Siwicki] $]^{84}$. Tego rodzaju znak oraz oprawy z okładzinami obciągniętymi skórą i zdobionymi grzbietami wskazują na zainteresowania bibliofilskie grodzieńskiego i choroskiego zakonnika. Należy zauważyć, że nota proweniencyjna na książce Karla Scherffera informuje, iż wcześniejszym jej właścicielem był dominikanin Laurenty Bartkiewicz. Stare druki z klemensowskiej kolekcji uzupełniają zatem wiedzę na temat tego cennego, ale rozproszonego księgozbioru ${ }^{85}$.

Oprawa jednego egzemplarza opatrzona jest heraldycznym superekslibrisem Zamoyskich, co zdaje się wskazywać na jej przynależność w 1815 r. do Biblioteki Ordynacji Zamoyskich ${ }^{86}$.

Często pojawia się napis rękopiśmienny informujący, od kogo biblioteka pozyskała daną książkę. Wśród ofiarodawców byli członkowie konwentu, którzy przyjmując habit, ofiarowali należące do nich egzemplarze. Tego rodzaju dane widnieją na kartach 28 woluminów. Zazwyczaj są to pojedyncze pozycje, ale też dary więcej niż jednoegzemplarzowe. Poza Dominikiem Siwickim cztery woluminy bibliotece klasztornej przekazał dwukrotny przeor miejscowego konwentu w latach 1736-

${ }^{83} \mathrm{O}$ badaniach proweniencyjnych, zob. m.in. M. Sipayłł, O metodzie badań proweniencyjnych starych druków, w: Z badań nad polskimi ksiegozbiorami historycznymi, Warszawa 1975, s. 9-29; M. Strutyńska, Struktura proweniencyjna zbioru starych druków Biblioteki Uniwersyteckiej w Toruniu. Przewodnik po zespołach. Problemy badawcze i metodologiczne, Toruń 1999.

${ }^{84}$ Ambrosius Calepinus, Dictionarium novem linquam, Lugduni Batavorum, Ex Typographia redidiva Abrahami Commelini, [br. r.w. XVII w.]; Nicolas Louis de Lacaille, Lectiones elementares mathematcae seu elementa algebrae et geometriae, Viennae, Pragae et Tergesti, Typis Joannis Thomae Trattnern, [1762]; Carlo Scherfer, Institutiones logicae et metaphisicae duabus partibus coprehensae conscriptae, Vindobonae, Typis Joannis Thomae Trattner, 1763; Litterae annuae Societatis Anno 1607 ad Patres et Fratres Soc[ietatis] Jesu, [br. m. r. wyd.]; Kozłowska, Starodruki z biblioteki, s. 140, 142.

${ }^{85}$ I. Pietrzkiewicz, Rękopiśmienna spuścizna Faustyna Ciecierskiego jako źródło do dziejów kultury intelektualnej dominikanów prowincji litewskiej początku XIX wieku, „Annales Universitatis Pedagogicae Cracoviensis. Studia ad Bibliothecarum Scientiam", (2013) s. 118; I. Pietrzkiewicz, Zbiory dominikanów grodzieńskich i ich opiekunowie, w: Arma Nostrae Militiae. Kultura ksią̇ki i pisma Zakonu Kaznodziejskiego na ziemiach polskich, red. I. Pietrzkiewicz, M. Miławicki, Warszawa 2019, s. 89-112; I. Pietrzkiewicz, Kultura ksiązki w zakonach męskich Wielkiego Księstwa Litewskiego XV-XVIII wieku, Kraków 2019, s. 194-196.

${ }^{86}$ Erasmus Desiderius Roterodamus, Apophtegmatum ex optimis utriusque lingva scriptoribus collectorum libri octo, Coloniae, Mart[inus] Gymnicus, 1547; J. Swastek, Erazm z Rotterdamu (1466-1536), niderlandzki filolog, filozof, pedagog, w: Encyklopedia katolicka, t. 4, red. R. Łukaszyk, L. Bieńkowski, F. Gryglewicz, Lublin 1984, kol. 1062-1063. 
1738 i 1741-1744 Damian Jurkiewicz ${ }^{87}$, trzy Rafael Januszkiewicz ${ }^{88}$, po dwa Kazimierz Strawiński ${ }^{89}$ i Bronisław Nargiełłowicz. Po jednej pozycji klasztorna biblioteka wzbogaciła się od Laurentego Bartkiewicza, Ferdynanda Józefa Grycewica ${ }^{90}$, Józefa Bonawentury Korzeniowskiego ${ }^{91}$, Hiacynta Kozakowskiego ${ }^{92}$, dominikańskiego kaznodziei w Petersburgu Klemensa Mayłowicza ${ }^{93}$, Bronisława Bargiełłowicza, Jana Romanowskiego"4, Jana Słuszka95, Justyna Sokulskiego, Reginalda Sołłohuba ${ }^{96}$, zmarłego w 1775 r. prowincjała prowincji litewskiej, protonotariusza apostolskiego, autora katalogu braci od początku konwentu wileńskiego Grzegorza Szymaka $^{97}$, Antoniego Wołłowicza oraz Aleksego Zborowskiego.

Wśród darczyńców były też osoby świeckie. Zazwyczaj przekazywano po jednej książce, ale w dwu przypadkach - Antoniego Czechowicza i notariusza wileńskiego Aleksandra Koncewicza - widnieją po dwa woluminy. Pojedyncze egzemplarze oddali klasztornej bibliotece: Michał Brauer z Rygi, Piotr Faustus Pendecki, Laurenty Rabczyński, Jakub Rudziński ${ }^{98}$, Antoni Stefanowicz ${ }^{99}$, Antoni Szwarc ${ }^{100}$, Bazyli Turowski i Antoni Andrzej Wieczorkowski. Jedna książka trafiła do księgozbioru ze skasowanego w 1773 r. kolegium jezuickiego w Pułtusku ${ }^{101}$.

${ }^{87}$ Rękopism X. Bagińskiego, s. 97. W latach 1729-1732 był przeorem w klasztorze dominikanów w Wołyńcu, zob. Pińsk, Kościót św. Dominika, https://radzima.org/pl/miejsce_comm/6144.ht$\mathrm{ml}$ (dostęp: 23.01.2020).

${ }^{88}$ Prawdopodobnie pochodził z litewskiego rodu Januszkiewiczów, h. Lubicz, zob. J. Ciechanowicz, Rody rycerskie Wielkiego Księstwa Litewskiego, t. 3: E-K, Rzeszów 2001, s. 199-202.

${ }^{89}$ Prawdopodobnie pochodził z litewskiego rodu Strawińskich, h. Sulima, Poraj, Szeliga, Hippocentaurus, Przyjaciel, zob. Ciechanowicz, Rody rycerskie, t. 4: $L-R$, s. 146-175.

${ }^{90}$ Prawdopodobnie pochodził z litewskiego rodu Grycewicz (Gricevićius), h. Topór, zob. Ciechanowicz, Rody rycerskie, t. 3, s. 99.

${ }^{91} \mathrm{~W} 1724$ r. był przeorem klasztoru w Pińsku, zob. Pińsk, Kościót św. Dominika.

${ }_{92}$ Prawdopodobnie pochodził z litewskiego rodu Kozakowskich, h. Lilia, Koziełł, zob. Ciechanowicz, Rody rycerskie, t. 3, s. 419.

${ }^{93}$ Prenumeratorowie, w: Wielki tydzień dla duchownego pożytku chrześcijan wszelkiego stanu, wyd. przez X. Jakuba Falkowskiego, Wilno 1829, s. XV.

${ }^{94}$ Prawdopodobnie pochodził z litewskiego rodu Romanowskich, h. Bończa, Boża Wola, Prawdzic, Przyjaciel, zob. Ciechanowicz, Rody rycerskie, t. 4, s. 419.

${ }^{95}$ Prawdopodobnie pochodził z jednego najstarszych i zasłużonych rodów na Litwie-Słuszków, h. Ostoja, zob. Ciechanowicz, Rody rycerskie, t. 5: S-Ż, s. 108.

${ }^{96}$ Prawdopodobnie pochodził z litewskiego rodu Sołohub vel Sołłohub, h. Prawdzic, zob. Ciechanowicz, Rody rycerskie, t. 5, s. 121-122.

${ }^{97}$ Rękopism X. Bagińskiego, s. 65-66.

${ }^{98}$ Prawdopodobnie pochodził z litewskiego rodu Rudzińskich, h. Prus, Prus III, Rawicz, Zaręba, zob. Ciechanowicz, Rody rycerskie, t. 4, s. 460-461.

${ }^{99}$ Prawdopodobnie pochodził z litewskiego rodu Stefanowiczów, h. Pogonia, Syrokomla, zob. Ciechanowicz, Rody rycerskie, t. 5, s. 140-142.

${ }^{100}$ Prawdopodobnie pochodził z litewskiego rodu Szwarców, h. Nowina, zob. Ciechanowicz, Rody rycerskie, t. 5, s. 40, 219.

${ }^{101}$ Zob. J. Szczepański, Kolegium jezuickie w Puttusku (1556-1772), w: Dzieje Gimnazjum i Liceum im. Piotra Skargi w Pultusku, Ciechanów, Pułtusk 1991, s. 18-54; Encyklopedia wiedzy, s. 553554. 
Noty proweniencyjne informują też o innych właścicielach książek z dominikańskiego księgozbioru zanim trafiły do Władysława Trębickiego. W dziewięciu tego rodzaju przypadkach pojawiają się Antoni Wołłowicz ${ }^{102}$, Kazimierz Minkiewicz $^{103}$, Antoni Walentynowicz, Jerzy i Franciszek Jamontowie, Antoni Kalinowski, Michał Staszewski, Józef Juszkiewicz, Antoni Czechowicz i kolegium jezuickie w Łucku ${ }^{104}$.

W przypadku czterech książek $\mathrm{z}$ danych proweniencyjnych dowiadujemy się o czasie włączenia ich do klasztornego księgozbioru. Trzy prace Leopolda Biwalda oraz Cosmologia generalis Johanna Christiana Wolfa trafily tam za przeoratu Ildefonsa Bylewskiego, który dwukrotnie pełnił tę funkcję w latach 1762-1765 i $1771-1774^{105}$.

Stare druki wileńskich dominikanów z klemensowskiej kolekcji posiadają różne oprawy, które są w różnym stanie zachowania. Samodzielnie oprawionych jest 78 pozycji bibliograficznych, pozostałych 14 jest współoprawnych. Dwa woluminy pozbawione są oprawy, cztery nie posiadają jednej z okładzin. Kolejne trzy mają okładziny obciągnięte brunatną skórą i ozdobne klamry. Pięć opraw posiada mniszy charakter - skórą obciągnięty jest grzbiet i do połowy drewniane okładziny. Pergaminową oprawę ma 13 książek, osiem papierową, a w trzech woluminach oprawy wykonane zostały w XIX stuleciu, do których użyto tektury i półskórka. Pozostałe 44 egzemplarze mają tekturowe, obciągnięte skórą okładziny (42 brunatną, 2 barwioną na zielono). Poddane zostały też zabiegom zdobniczym przy użyciu techniki tłoczenia na ślepo i tłoczenia złotem. Ornamenty charakteryzują się motywami roślinnymi. Ponadto 20 oprawionych książek posiada na grzbiecie wytłoczony tytuł dzieła. W siedmiu książkach karty cyzelowane są na kolor czerwony i brązowy. Taka sama kompozycja i motywy zdobnicze na tych oprawach pozwalają wnioskować, że mogą być one dziełem jednego warsztatu introligatorskiego i mogły być wykonane na zamówienie dominikanów, ponieważ posiadają tylko ekslibris macierzystej książnicy.

Zamojski fragment wileńskiego księgozbioru dominikańskiego zawiera woluminy, które pozostawały w żywym obiegu. Większość z nich nosi ślady użytkowania. Noty marginalne i interlinearne - przeważnie nieczytelne (zamazane, przekreślone) - mają charakter odniesień do innych autorów lub innych części dzieła. Pochodzą z różnych okresów i są dziełem wielu rąk, o czym świadczy zróżnicowany kolor atramentu oraz zindywidualizowany dukt pisma. Najczęściej występują podkreślenia, świadczące o intensywnym sposobie lektury, kierujące uwagę na fragmenty godne zapamiętania. Warto jednak zaznaczyć, że nie są one naduży-

102 Prawdopodobnie chodzi o Antoniego Wołłowicza, chorążego Wielkiego Księstwa Litewskiego, zm. 1822, zob. Urzędnicy Wielkiego Księstwa Litewskiego. Spisy, t. 2: Województwo trockie XIV-XVIII wiek, red. A. Rachuba, oprac. H. Lulewicz i in., Warszawa 2009, s. 544 nr 4068.

${ }^{103}$ Prawdopodobnie chodzi o Kazimierza Minkiewicza, cześnika smoleńskiego, żyjącego na przełomie XVII i XVIII wieku, zob. Urzędnicy Wielkiego Księstwa Litewskiego. Spisy, t. 1: Województwo wileńskie XIV-XVIII wiek, red. A. Rachuba, oprac. H. Lulewicz, A. Rachuba, P.P. Romaniuk, Warszawa 2004, s. 273, nr 1771.

${ }^{104}$ Encyklopedia wiedzy, s. 393.

${ }^{105}$ Rękopism X. Bagińskiego, s. 97. 
wane, co wynikało zapewne z przepisów zakonnych zabraniających robić prywatne notatki na kartach książek. O użytkowaniu woluminów świadczą również ślady po przewracaniu kart, poczerniałe, pozaginane, a w wielu przypadkach urwane fragmenty kart. Wszystkie mają przycięte brzegi.

Wiele starych druków wyszło spod pras znanych i cenionych oficyn typograficznych, reprezentujących kulturę drukarską różnych krajów, w różnym okresie. Pokazują zatem drogi przemieszczania się książki po Europie oraz dostępność do określonych dzieł przez polskich użytkowników. Mogły być przywożone do Polski za pośrednictwem profesjonalnych handlarzy książką, ale też w wyniku importu indywidualnego. Wielu bowiem użytkowników i miłośników książki, w tym również osób duchownych, w trakcie podróży zagranicznych nabywało i przywoziło do kraju interesujące ich dzieła. Woluminy przechowywane w Książnicy Zamojskiej świadczą o tym, że ich import indywidualny czy ewentualne zakupy nie były przypadkowe. Są one bowiem dziełem znanych i uznanych autorów, były studiowane i wykorzystywane w różnego rodzaju działalności, czy to kształceniowej, czy duszpasterskiej. Wynikało to być może z przyjętej i realizowanej polityki gromadzenia księgozbioru mówiącej o tym, że książki rzadko używane i dublety sprzedawano, a za uzyskane w ten sposób środki kupowano te, które były potrzebne. Sprawiało to, że księgozbiór, przynajmniej jego fragment z kolekcji klemensowskiej, ma zwarty charakter. Kierują również uwagę na kulturę duchową i intelektualną wileńskich dominikanów, bowiem obieg treści piśmienniczych był i jest żywym oraz realnie funkcjonującym zjawiskiem. Szkolnictwo i biblioteki dominikańskie realizowały program formacyjny istotny z punktu widzenia życia zakonnego i duszpasterskiego, ustalały i wdrażały w świadomość zakonników, a za ich pośrednictwem wiernym, określony kanon pisarzy i dzieł oraz ich oceny, formułowane z punktu widzenia potrzeb zbiorowości, którą tworzyły i na którą oddziaływały. Celem, jaki przyświecał tym działaniom, było zaspokajanie aktualnych potrzeb konwentu dominikańskiego i kształtowanie nowych. Dostarczają ponadto cennych danych odnoszących się do księgozbiorów donatorów konwentu i ich ewentualnych zainteresowań bibliofilskich oraz skomplikowanych losów dziejowych klasztornej librarii. Są ważną cząstką pozwalającą na jej rekonstrukcję, co w sytuacji rozproszenia księgozbioru stanowi istotny krok w tym kierunku. 


\section{Źródla}

\section{REFERENCES / BIBLIOGRAFIA}

Lietuvos Valstybės Istorijos Archywas (LVIA)

sygn. F.1135-8-10, Archiwum historyka Władysława Zahorskiego.

Archiwum OO. Dominikanów w Krakowie (ADKr)

sygn. I.c.III 76/252, Teka wileńska.

Akta unji Polski z Litwa, 1385-1791, wyd. S. Kutrzeba i W. Semkowicz, Kraków 1932.

Constitutiones, declarationes et ordinationes capitulorum generalium Sacri Ordinis Fratrum Praedicatorum ab anno 1220 usque ad 1650 emantae, Prima pars tables, red. Vincentino Fontana, Romae 1862.

Księga konstytucji i zarządzeń Zakonu Braci Kaznodziejów: statut polskiej prowincji Zakonu Braci Kaznodziejów, oprac. P. Krzysztofiak, tłum. J. Janczak, M. Wylęgała, Warszawa 1996.

\section{Opracowania}

Bautz Friedrich Wilhelm, Franz Wolfgang, w: Biographisch-Bibliographisches Kirchenlexikon, t. 2, Hamm 1990, sp. 112.

The Bloomsbury Dictionary of Eighteenth-Century German Philosophers, red. H.F. Klemme, M. Kuehn, London 2016, s. 319-320.

Brzozecki Sławomir, Litewska prowincja dominikanów, w: Dominikanie-Gdańsk-Polska -Europa: materiaty z konferencji międzynarodowej, red. D.A. Dekański, A. Gołembnik, M. Grubka, Gdańsk 2003, s. 139-165.

Brzozecki Sławomir, Górniak Robert Marek, Tomasz z Akwinu, w: Encyklopedia katolic$k a$, t. 19, red. E. Gigilewicz, Lublin 2013, kol. 848-852.

Bruins Everet Marie, On the history of logarithms. Bürgi, Napier, Briggs, de Decker, Vlacq, Huygens, ,Janus”, 67 (1980), s. 241-260.

Brück Anton Ph., Goldhagen Herman, w: Neue Deutsche Biographie, t. 6, Berlin 1964, s. 605.

Chwalewik Edward, Zbiory polskie: archiwa, biblioteki, gabinety, galerje, muzea i inne zbiory pamiątek przeszłości w ojczyźnie i na obczyźnie, t. 2, Warszawa-Kraków 1927.

Ciechanowicz Jan, Rody rycerskie Wielkiego Księstwa Litewskiego, t. 3-5, Rzeszów 2001.

Cytowska Maria, Szelest Hanna, Literatura rzymska. Okres augustowski, Warszawa 1990. Cytowska Maria, Szelest Hanna, Literatura rzymska. Okres cesarstwa, Warszawa 1992.

Deptuła Czesław, Iwon Odroważ, bp, zm. 20 lub 21 VIII 1229, w: Encyklopedia katolicka, t. 7, red. S. Wielgus, Lublin 1977, kol. 579-580.

Garniewicz Janusz, Swiatynie wileńskie od czasów najdawniejszych do obecnych, Kędzierzyn-Koźle 1993.

Giżycki Jan Marek Antoni, Wiadomości o dominikanach prowincji litewskiej, cz. 1, Kraków 1917.

Glass Ian Steward, Nicolas - Louis de La Caille, Astronomes and Geodesist, Oxford 2013.

Hamilton James Robertson, The date of Quintus Curtius Rufus, „Zeitschrift für Alte Geschichte", 37 (1988) nr 4, s. 445-456.

Jacobs Eduard, Wolf Johann Christian, w: Allgemeine Deutsche Biographie, t. 43, Leipzig 1898, s. 761. 
Juda Maria, Kultura intelektualna i duchowa dominikanów wileńskich w świetle inwentarza biblioteki z I połowy XVII wieku, „Archiwa, Biblioteki i Muzea Kościelne”, 114 (2020) s. 123-143.

Kłoczowski Jerzy, Dominikanie, w: Encyklopedia katolicka, t. 4, red. R. Łukaszyk, L. Bieńkowski, F. Gryglewicz, Lublin 1985, kol. 69-76.

Kłoczowski Jerzy, Dominikanie w środkowo-wschodniej Europie i ich kultura intelektualna oraz pastoralna $w$ wiekach średnich, w: Dominikanie $w$ środkowej Europie $w$ XII-XV wieku. Aktywność duszpasterska i kultura intelektualna, J. Kłoczowski, J.A. Spież, Poznań 2002, s. 153-172.

Kłoczowski Jerzy, Młodsza Europa. Europa Środkowo-Wschodnia w kręgu cywilizacji chrześcijańskiej średniowiecza, Warszawa 1998.

Kłoczowski Jerzy, Wspólnoty chrześcijańskie. Grupy życia wspólnego w chrześcijaństwie zachodnim od starożytności do XV wieku, Kraków 1964.

Kłoczowski Jerzy, Zakon dominikański i początki wyższego szkolnictwa na ziemiach polskich, w: Dominikanie-Gdańsk-Polska-Europa: materiały z konferencji międzynarodowej, D.A. Dekański, A. Gołembnik, M. Grubka, Gdańsk 2003, s. 67-88.

Korneliusz Nepos. Żywoty wybitnych mężów, wstęp, komentarz i red. L. Winniczuk, Warszawa 1974.

Kozłowska Iwona Monika, Starodruki z biblioteki O.O. Dominikanów z Wilna w Bibliotece im. H. Łopacińskiego w Lublinie, Lublin 1999, praca magisterska, Archiwum UMCS.

Kraszewski Józef Ignacy, Wilno od początków jego do roku 1750, t. 2, 4, Wilno 1842.

Kuczyński Stefan Maria, Holszański Aleksander Jurjewicz, w: Polski stownik biograficz$n y$, t. 9, red. K. Lepszy, Wrocław 1960, s. 586-587.

Łuszczyńska Maria, Trębicki Władysław, w: Słownik pracowników książki polskiej, red. I. Treichel, Warszawa 1972, s. 909.

Łuszczyńska Maria, Szwarc Wanda, Władysław Trębicki zapomniany bibliofil i bibliograf XIX wieku, „Bibliotekarz Lubelski”, (1959) nr 4, s. 17-25.

Migoń Krzysztof, Bibliologia-nauka o kulturze książi, w: Encyklopedia ksią̇ki, A. Żbikowska-Migoń, i M. Skalska-Zlat, t. 1: Eseje·A-J, Wrocław 2017, s. 23-32.

Miławicki Marek, Inwentarze i spisy klasztorów dominikańskich skasowanych w guberniach zachodnich Cesarstwa Rosyjskiego w XIX w. Stan źródet i miejsca ich przechowywania, „Haereditas Monasteriorum”, 1 (2012) s. 141-172.

Morelowski Marian, Znaczenie baroku wileńskiego XVIII stulecia, Wilno 1940, s. 29.

Nakcjanowicz (Nakcyanowicz) Jakub, w: Encyklopedia wiedzy o jezuitach na ziemiach Polski i Litwy 1564-1995, oprac. L. Grzebień SJ przy współpracy zespołu jezuitów, Kraków 2004, s. 450.

Nieścior Celina, Księgozbiór klemensowski w Bibliotece im. H. Łopacińskiego, „Bibliotekarz Lubelski”, (1959) nr 1-2, s. 6-8.

Nitecki Piotr, Biskupi Kościoła w Polsce w latach 965-1999. Słownik biograficzny, Warszawa 2000.

Orszewska Barbara, Klejnoty wileńskie, Wilno 2002.

Pietrzkiewicz Iwona, Kultura książki w zakonach męskich Wielkiego Księstwa Litewskiego XV-XVIII wieku, Kraków 2019.

Pietrzkiewicz Iwona, Rękopiśmienna spuścizna Faustyna Ciecierskiego jako źródło do dziejów kultury intelektualnej dominikanów prowincji litewskiej poczatku XIX wieku, „Annales Universitatis Pedagogicae Cracoviensis. Studia ad Bibliothecarum Scientiam", (2013) nr 11, s. 103-123. 
Pietrzkiewicz Iwona, Zbiory dominikanów grodzieńskich i ich opiekunowie, w: Arma Nostrae Militiae. Kultura ksiązki i pisma Zakonu Kaznodziejskiego na ziemiach polskich, red. I. Pietrzkiewicz, M. Miławicki, Warszawa 2019, s. 89-112.

Podbielski Henryk, Arystoteles - życie i twórczość, w: Literatura Grecji starożytnej, red. H. Podbielski, t. 2: Proza historyczna, krasomówstwo, filozofia i nauka, literatura chrześcijańska, Lublin 2005, s. 661-726.

Podręczna encyklopedia kościelna, t. 9-10, red. Z. Chełmicki, Warszawa 1906.

Radziszewski Franciszek, Wiadomość historyczno-statystyczna o znakomitszych bibliotekach $i$ archiwach publicznych i prywatnych tak niegdyś bytych jako i obecnie istniejacych $w$ krajach dawna Polska składających, a mianowicie: w Królestwie Polskiem, Galicyi W. Ks. Poznańskiem i Zachodnich guberniach Państwa Rossyjskiego porzadkiem abecadłowym miejsc ułożona przez, Kraków 1875.

Rękopism X. Bagińskiego dominikanina prowincji litewskiej (1747-1784), wyd. przez E. Tyszkiewicza, Wilno 1854.

Romaniuk Przemysław P., Sołłohub Antoni Józef, w: Polski słownik biograficzny, t. 40, red. H. Markiewicz, Warszawa 2000, s. 308.

Rys dziejów zakonu kaznodziejskiego w Polsce, ułożył S. Barącz, t. 2. Lwów 1861.

Schmutz Jacob, Duhan Laurent (ok. 1656-1726), w: Dictionary of Seventeenth-Century French Philosophers, t. 1, red. L. Foisneau, London-New York 2008, s. 390-392.

Sipayłł Maria, O metodzie badań proweniencyjnych starych druków, w: Z badań nad polskimi księgozbiorami historycznymi, z. 1, Warszawa 1975, s. 9-29.

Spież Jan Andrzej, Dominikanie w Polsce, w: Chrześcijańska odpowiedź na pytanie człowieka. W 750-lecie stużby polskich dominikanów Bogu i ludziom, Warszawa 1974.

Stabryła Stanisław, Historia literatury starożytnej Grecji i Rzymu, Wrocław 2002.

Stolarczyk Tomasz, Analecta Dominiciana. Szkice z dziejów Zakonu Braci Kaznodziejów w Polsce Środkowej (XIII-XVIII wiek), Wieluń 2016.

Strutyńska Maria, Struktura proweniencyjna zbioru starych druków Biblioteki Uniwersyteckiej w Toruniu. Przewodnik po zespołach. Problemy badawcze i metodologiczne, Toruń 1999.

Swastek Józef, Erazm z Rotterdamu, w: Encyklopedia katolicka, t. 4, red. R. Łukaszyk, L. Bieńkowski, F. Gryglewicz, Lublin 1984, kol. 1062-1063.

Szczepański Janusz, Kolegium jezuickie w Pułtusku (1556-1772), w: Dzieje Gimnazjum i Liceum im. Piotra Skargi w Pułtusku, red. D. Ciok, A. Kociszewski, J. Szczepański, Ciechanów-Pułtusk 1991, s. 18-54.

Szostek Irena, Biblioteka dominikanów lwowskich $w$ świetle katalogu z roku 1776, w: Studia nad historia dominikanów w Polsce 1222-1972, red. J. Kłoczowski, Warszawa 1975, s. 409-462.

Świętochowski Robert, Szkolnictwo teologiczne dominikanów, w: Dzieje teologii katolickiej w Polsce, red. M. Rechowicz, t. 2: Od Odrodzenia do Oświecenia, Lublin 1975, s. 253-254.

Tyszkiewicz Eustachy, O klasztorach zgromadzeń istniejacych obecnie w diecezji Wileńskiej: Dominikanie, „Teka Wileńska”, 3 (1859) s. 223-273.

Urbańczyk Stanisław, Stowniki, ich rodzaje i użyteczność, [Wrocław] 1964.

Urzędnicy Wielkiego Księstwa Litewskiego. Spisy, t. 1: Województwo wileńskie XIV-XVIII wiek, red. A. Rachuba, oprac. H. Lulewicz, A. Rachuba, P.P. Romaniuk, Warszawa 2004.

Urzędnicy Wielkiego Księstwa Litewskiego. Spisy, t. 2: Województwo trockie XIV-XVIII wiek, red. A. Rachuba, oprac. H. Lulewicz i in., Warszawa 2009. 
Wegele Franz Xaver von, Pappus Leonard (1607-1677), w: Allgemeine Deutsche Biographie, t. 25, Leipzig 1887, s. 164-165.

Wielki tydzień dla duchownego pożytku chrześcian wszelkiego stanu, wyd. przez X. Jakuba Falkowskiego, Wilno 1829, s. XV.

Wittig Wiktor, Ex-librisy bibliotek polskich XVII i XVIII wieku, Warszawa 1903.

Wurzbach Constantin von, Biwald Leopold Gottlieb (1731-1805), w: Biographisches Lexicon des Kaiserthums Oesterreich, cz. 1, red. L.C. Zamarski, Wien 1856, s. 415.

Zielińska Zofia, Pociej Ludwik, w: Polski stownik biograficzny, t. 27, red. E. Rostworowski, Wrocław 1983, s. 47-49.

\section{Netografia}

Książnica Zamojska im. Stanisława Kostki Zamoyskiego w Zamościu, http://www.biblioteka.zamosc.pl.cyfrowa.biblioteka.zamosc.pl/dlibra/collectiondescription?dirids=4 (dostęp: marzec 2019-styczeń 2020).

Masius, Didactus, CERL Thesaurs, https://data.cerl.org/thesaurus/cnp00991500 (dostęp: 23.01.2020).

Delvaux, André, CERL Thesaurs, https://data.cerl.org/thesaurus/cnp01353402 (dostęp: 24.01.2020).

Luís António Verney, Escritores Lusófonos, escritoreslusofonos.net/2018/11/23/luis-antonio-verney (dostęp: 24.01.2020).

Diego Ortiz de Zúñiga, Real Academia de la Historia, dbe.rah.es/biografias/7529/diego-ortiz-de-zuniga (dostęp: 26.01.2020).

Pere Nicolau Arnu, Gran enciclopèdia catalana, https:/www.enciclopedia.cat/ecgec-0005305.xml (dostęp: 24.01.2020).

Goudin, Antoine, Encyclopedia.com, https://www.encyclopedia.com/religion/encyclopedias-almanacs-transcripts-andmaps/goudin-antoine (dostęp: 23.01.2020).

Jesuitscience.net, jesuitscience.net/p/1009 (dostęp: 24.01.2020).

pw.kasaty.pl (dostęp : 10.09.2019)

Pińsk, Kościót św. Dominika, https://radzima.org/pl/miejsce_comm/6144.html (dostęp: 23.01.2020).

Worldcat.org, https://www.worldcat.org (dostęp: 03.09.2019). 


\title{
FRAGMENT OF THE BOOK COLLECTION OF VILNIUS DOMINICANS IN THE KLEMENSÓW COLLECTION OF THE ZAMOJSKI LIBRARY NAMED AFTER STANISLAW KOSTKA ZAMOYSKI
}

\begin{abstract}
Old prints, part of the Vilnius Dominican collection, currently held in the Zamojski Library named after Stanisław Kostka Zamoyski, originate from the 16 th, 17 th and 18th centuries and are the product of numerous foreign and domestic publishing houses. The collection of 92 bibliographic items includes works relating to various areas of human knowledge at the time but is directed at the needs of the congregation. The books were intended to serve the members of the convent in their pastoral and educational work. The provenance marks and notes show the previous owners of individual copies and the methods of collecting them, as well as the traces of use by actual readers. They are an important contribution to the reconstruction of this scattered book collection.
\end{abstract}

Keywords: book; old print; library; Dominicans; Vilnius; Zamojski Library

Translated by Grzegorz Knyś 